\title{
Pengaruh pendekatan pembelajaran berbasis masalah untuk meningkatkan kemampuan komunikasi matematis siswa
}

\section{Nur Rahmi Rizqi}

STKIP Asy-Syafi'iyah Internasional Medan, Medan, Sumatera Utara, Indonesia, 20144

\section{Lilis Arini*}

STKIP Asy-Syafi'iyah Internasional Medan, Medan, Sumatera Utara, Indonesia, 20144

*Corresponding Author: lilisarini1993@gmail.com

\begin{abstract}
This study aims to determine the effect of problem-based learning approaches to improve students' mathematical communication skills. The study was conducted at SMP Negeri 1 Pangkalan Susu in the odd semester of the $2019 / 2020$ school year with a population of all grade VII students and a sample of 30 students. The instrument uses a validated test. Both classes were given a post-test after treatment. Before testing the hypothesis, the requirements are normality test, it turns out that both data are normally distributed and the homogeneity test turns out to be both homogeneous data. From the results of hypothesis testing using the $\mathrm{t}$-test obtained $\mathrm{t}_{\text {count }}(3.018)>\mathrm{t}_{\text {table }}(1.671)$ where Ha is received. From the determination test results obtained $13.6 \%$ while $86.4 \%$ influenced by other factors. This means that there is an influence of the use of problem-based learning on mathematical communication skills of students of SMP Negeri 1 Pangkalan Susu.
\end{abstract}

Historis Artikel:

Diterima: 1 Maret 2020

Direvisi: 7 Maret 2020

Disetujui: 28 Maret 2020

\section{Keywords:}

Mathematical

communication ability, problem based learning

Sitasi: Rizqi, N. R., \& Arini, L. (2020). Pengaruh pendekatan pembelajaran berbasis masalah untuk meningkatkan
kemampuan komunikasi matematis siswa. Journal of Didactic Mathematics, 1(1), $22-26$.
https://doi.org/10.34007/jdm.v1i1.148

\section{PENDAHULUAN}

Dilihat dari perolehan TIMSS (Trends In International Mathematics and Science Study) tahun 2011 menempatkan Indonesia pada peringkat ke-38 dari 42 negara. Selain itu, PISA (Programme for International Student Assessment) tahun 2012 menempatkan Indonesia pada peringkat ke-64 untuk bidang matematika dari 65 negara yang ikut ambil bagian. (Kompas: 2012). Dari hasil tersebut dapat dijadikan salah satu evaluasi dari berhasil tidaknya pelaksanaan pembelajaran matematika di Indonesia, selain sebagai alat kompetisi yang memotivasi guru dan semua pihak dalam dunia pendidikan untuk lebih meningkatkan prestasinya. Rendahnya rating matematika yang diperoleh Indonesia menjadi fokus masalah dalam pendidikan Indonesia.

Salah satu kemampuan yang harus dimiliki siswa agar terjadi peningkatan dalam belajar matematika adalah kemampuan komunikasi matematis. Karena dengan komunikasi dalam matematika peserta didik akan memiliki keterangan, data, dan fakta tentang pemahaman mereka dalam melakukan proses dan aplikasi matematika. Melalui komunikasi siswa dapat mengorganisasi dan mengonsolidasi berpikir matematikanya dan siswa dapat mengeksplorasi ide-ide matematika.

Dengan komunikasi, siswa dapat menjelaskan atau menyampaikan ide-ide dan konsepkonsep matematika, disamping itu terjadi respon antar siswa dalam proses pembelajaran. Pada akhirnya dapat membawa siswa pada pemahaman yang lebih mendalam tentang konsep matematika yang telah dipelajari.

Menurut Baroody (Ansari, 2012:4) menyebutkan sedikitnya ada dua alasan penting mengapa kemampuan komunikasi matematis perlu ditumbuhkembangkan dikalangan siswa. Pertama, mathematics as language, artinya matematika tidak hanya sekedar alat bantu berpikir (a tool to aid 
Pengaruh pendekatan pembelajaran berbasis masalah untuk meningkatkan...

thinking), alat untuk menemukan pola, menyelesaikan masalah atau mengambil kesimpulan, tetapi matematika juga sebagai alat yang berharga untuk mengkomunikasikan berbagai ide secara jelas, tepat dan cermat. Kedua, mathematics learning as social activity; artinya, sebagai aktivitas sosial dalam pembelajaran matematika, matematika juga sebagai wahana interaksi antar siswa, dan juga komunikasi antara guru dan siswa.

Namun kenyataan di lapangan menunjukkan kemampuan komunikasi matematis siswa masih rendah, yaitu berdasarkan soal komunikasi yang diberikan kepada siswa. Rendahnya komunikasi matematis siswa diperkuat oleh Saragih dan Rahmiyana (2013: 176), berdasarkan hasil observasi dari ulangan harian yang dilakukan pada siswa SMA/MA Negeri Simpang Ulim, menunjukkan bahwa kemampuan komunikasi matematika masih rendah, hal ini dapat dilihat dari proses jawaban siswa hampir semua siswa mengalami kesulitan menggambarkan masalah yang diberikan. Hanya 6 orang dari 15 siswa SMA dan 2 orang yang mampu menggambarkan permasalahan tersebut dalam bentuk gambar, walaupun kurang sempurna. Tidak satu orang pun siswa dari kedua sekolah dapat menentukan model matematika yang sesuai, dikarenakan kurang sempurnanya gambar pada poin a), sehingga siswa tidak dapat menentukan tinggi tiang lampu dengan benar. Ada 2 orang siswa dari SMA dan 3 orang siswa MA yang menjawab poin c) tidak satu orang pun siswa yang mencoba menceritakan cara menyelesaikan masalah. Ini dikarenakan dalam proses pembelajaran guru hanya menjelaskan langkah-langkah untuk sekedar menghitung tanpa membimbing siswa untuk mengemukakan ide dalam bentuk lisan dan tulisan.

Rendahnya kemampuan komunikasi matematis siswa ini disebabkan oleh banyak faktor, diantaranya orientasi pendidikan di Indonesia umumnya memperlakukan peserta didik berstatus sebagai obyek, guru sebagai pemegang otoritas tertinggi keilmuan dan materi bersifat subject-oriented. Handayani, dkk (2014:1) mengatakan pembelajaran yang berpusat pada guru, mengakibatkan siswa pasif dalam pembelajaran di kelas. Seringkali para guru mengontrol secara penuh materi serta metode penyampaiannya. Akibatnya, proses pembelajaran matematika di kelas saat itu menjadi proses mengikuti langkah-langkah, aturan-aturan, serta contoh-contoh yang diberikan guru. Dengan model pembelajaran seperti itu, keaktifan siswa menjadi sangat rendah. Pembelajaran matematika seperti yang dikemukakan di atas, tidak memberikan kebebasan berpikir kepada siswa, melainkan belajar hanya untuk tujuan yang singkat. Sehingga menyebabkan komunikasi matematis siswa rendah.

Salah satu pendekatan pembelajaran yang sesuai dengan gerakan perubahan tersebut adalah Pendekatan Pembelajaran Berbasis Masalah. Pembelajaran Berbasis Masalah (PBM) adalah salah satu pembelajaran yang berpusat pada peserta didik dengan cara menghadapkan peserta didik dengan berbagai masalah yang dihadapi dalam kehidupannya. Dengan kata lain model pembelajaran berbasis masalah merupakan suatu model pembelajaran yang menantang siswa untuk "belajar bagaimana belajar", bekerja secara berkelompok untuk mencari solusi dari permasalahan dunia nyata. Hal tersebut sejalan dengan pendapat Arends (2008:45) bahwa "PBL melibatkan siswa untuk menginterpretasikan dan menjelaskan berbagai fenomena dunia nyata dan untuk mengkonstruksikan pemahaman mereka sendiri tentang fenomena tersebut". Masalah yang diberikan ini digunakan untuk mengikat siswa pada rasa ingin tahu pada pembelajaran yang dimaksud. Kurikulum PBM memfasilitasi keberhasilan memecahkan masalah, komunikasi, kerja kelompok dan keterampilan interpersonal dengan lebih baik dibanding pendekatan yang lain, hal tersebut sejalan dengan Amir (2013:49) "bahwa dengan PBM yang dilakukan dalam kelompok pembelajaran mendapatkan lebih banyak kecakapan yaitu kecakapan memecahkan masalah, kecakapan berpikir kritis, kecakapan bekerja dalam kelompok, kecakapan interpersonal dan komunikasi serta kecakapan pencarian dan pengolahan informasi. Selanjutnya Elfrida (2013) dalam penelitiannya menyatakan bahwa penerapan pembelajaran berbasis masalah dapat meningkatkan kemampuan komunikasi matematis siswa hal tersebut dapat dilihat dari peningkatan rata-rata antara siklus 1 dan siklus 2 yaitu dari 70 - 81,82. Hal itu sejalan dengan penelitian Saylan (2013) bahwa kemampuan komunikasi matematis siswa dengan menggunakan pembelajaran berbasis masalah lebih baik dari pembelajaran biasa. 


\section{METODE}

Populasi penelitian ini adalah seluruh siswa kelas VII pada SMP Negeri 1 Pangkalan Susu pada semester ganjil tahun ajaran 2019/2020 yang terdiri dari 9 kelas. Sedangkan sampel dalam penelitian ini dipilih secara acak yaitu kelas VII-1 dan VII-2 yang berjumlah masing-masing 30 siswa dimana tingkat kemampuan siswanya heterogen, siswa kelas VII-1 ditetapkan sebagai kelas eksperimen dan kelas VI1-2 ditetapkan sebagai kelas kontrol. Adapun instrument dalam penelitian ini adalah tes kemampuan komunikasi matematis berupa pretes dan posttes pada materi bilangan.

\section{HASIL DAN PEMBAHASAN}

Berdasarkan hasil deskripsi data skor pretest kemampuan komunikasi matematis disajikan melalui tampilan output SPSS 23 pada lampiran dan dirangkum pada tabel 1 berikut ini:

Tabel 1. Descriptive Statistics Skor Post test Kelas Eksperimen dan Kontrol

\begin{tabular}{clcc}
\hline \multirow{2}{*}{ No } & Ukuran Statistik & \multicolumn{2}{c}{ Posttest } \\
\cline { 3 - 4 } & Jumlah Siswa & Kelas Eksperimen & Kelas Kontrol \\
\hline 2 & Jumlah Skor & 30 & 30 \\
\hline 3 & Skor Maksimum & 2266 & 1997 \\
\hline 4 & Skor Minimum & 90 & 80 \\
\hline 5 & Rata-Rata & 55 & 47 \\
\hline 6 & Simpangan Baku & 75,53 & 66,57 \\
\hline 7 & Varians & 6,92 & 8,86 \\
\hline
\end{tabular}

Pada tabel 1 diatas terlihat bahwa perhitungan data kemampuan komunikasi matematis diatas terlihat perbedaan rata-rata posttest kelas eksperimen dan kelas kontrol.

Sebelum dilakukan uji hipotesis terhadap data hasil penelitian yang telah diperoleh, maka terlebih dahulu dilakukan uji normalitas data dimaksudkan untuk menguji apakah data berdistribusi normal atau tidak. Pada penelitian ini, digunakan uji normalitas Kolmogorov-Smirnov. Dari hasil perhitungan dengan menggunakan bantuan software SPSS 23 diperoleh data output SPSS 23 sebagai berikut:

Tabel 2. Uji Normalitas Posttest Kelas Eksperimen dan Kelas Kontrol

\section{Tests of Normality}

\begin{tabular}{llrrrrrrr}
\hline \multirow{2}{*}{ Kelas } & \multicolumn{3}{c}{ Kolmogorov-Smirnov $^{\mathrm{a}}$} & \multicolumn{3}{c}{ Shapiro-Wilk } \\
\cline { 3 - 9 } & & Statistic & df & Sig. & Statistic & df & \multicolumn{1}{c}{ Sig. } \\
\hline \multirow{2}{*}{ Posttest } & kelas PBM & .155 & 30 & .064 & .893 & 30 & .006 \\
\cline { 2 - 9 } & kelas kontrol & .147 & 30 & .097 & .935 & 30 & .068 \\
\hline
\end{tabular}

\section{a. Lilliefors Significance Correction}

Berdasarkan tabel diatas bahwa nilai signifikansi posttest pada kelas PBM adalah 0,064 dan kelas kontrol adalah 0,097. Maka dapat disimpulkan bahwa uji normalitas data posttest kelas eksperimen dan kelas kontrol merupakan data yang berdistribusi normal. Pengujian homogenitas varians dapat dilanjutkan karena data pada kedua kelompok (kontrol dan eksperimen) berdistribusi normal. Pengujian kecocokan (homogenitas) varians terhadap kelompok kontrol dan kelompok eksperimen dengan taraf signifikansi $\alpha=0,05$. Uji homogenitas dilakukan dengan menggunakan uji Homogenity of Variances (Levene Statistic).

Hasil perhitungan uji homogenitas pretest dan posttest kelas eksperimen dan kelas kontrol disajikan dalam Output Test of homogenity of variance pada tabel 3 berikut ini: 
Pengaruh pendekatan pembelajaran berbasis masalah untuk meningkatkan...

Tabel 3. Uji Homogenitas Posttest Kemampuan komunikasi matematis

\section{Test of Homogeneity of Variances}

posttest

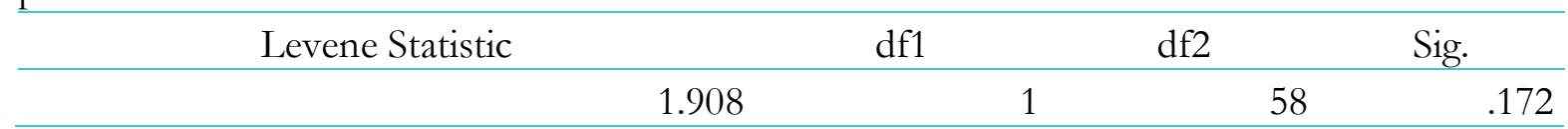

Berdasarkan tabel diatas memberikan nilai significance (sig.) $=0,172>\alpha=0,05$ maka berdasarkan kriteria pengujian dapat disimpulkan bahwa kedua sampel memiliki varians yang sama atau syarat homogenitas terpenuhi. Dari hasil uji hipotesis menerapkan teknik uji T. Rangkuman hasil analisis tersebut disajikan dalam tabel berikut:

Tabel 4. Hasil Uji Hipotesis Kemampuan Komunikasi Matematis

\begin{tabular}{|c|c|c|c|c|c|c|c|c|c|c|}
\hline \multicolumn{11}{|c|}{ Independent Samples Test } \\
\hline & & \multicolumn{4}{|c|}{$\begin{array}{c}\text { Levene's Test } \\
\text { for Equality of } \\
\text { Variances }\end{array}$} & \multicolumn{3}{|c|}{ t-test for Equality of Means } & & \\
\hline & & \multirow[t]{2}{*}{$\mathrm{F}$} & \multirow[t]{2}{*}{ Sig. } & \multirow[t]{2}{*}{$\mathrm{t}$} & \multirow[t]{2}{*}{ df } & \multirow[t]{2}{*}{$\begin{array}{l}\text { Sig. (2- } \\
\text { tailed) }\end{array}$} & \multirow[t]{2}{*}{$\begin{array}{c}\text { Mean } \\
\text { Difference }\end{array}$} & \multirow[t]{2}{*}{$\begin{array}{l}\text { Std. Error } \\
\text { Difference }\end{array}$} & \multicolumn{2}{|c|}{$\begin{array}{l}95 \% \text { Confidence } \\
\text { Interval of the } \\
\text { Difference }\end{array}$} \\
\hline & & & & & & & & & Lower & Upper \\
\hline \multirow[t]{2}{*}{ Posttest } & $\begin{array}{l}\text { Equal variances } \\
\text { assumed }\end{array}$ & 1.908 & .172 & 3.018 & 58 & .004 & 5.433 & 1.800 & 1.829 & 9.037 \\
\hline & $\begin{array}{l}\text { Equal variances } \\
\text { not assumed }\end{array}$ & & & 3.018 & 52.925 & .004 & 5.433 & 1.800 & 1.822 & 9.045 \\
\hline
\end{tabular}

Berdasarkan tabel pada kolom T-Test for Equality of Means terlihat hasil thitung sebesar 3,018 dan $t_{\text {tabel }}$ dengan $\mathrm{dk}=58$ sebesar 1,671 dengan signifikan lebih kecil dari 0,05. Artinya $\mathrm{H}_{0}$ ditolak dan $\mathrm{H}_{\mathrm{a}}$ diterima. Sehingga dapat disimpulkan bahwa rata-rata kemampuan komunikasi matematis kelas eksperimen lebih besar dari rata-rata kelas kontrol. Artinya terdapat pengaruh penerapan pendekatan pembelajaran berbasis masalah terhadap kemampuan komunikasi matematis matematika pada siswa SMP Negeri 1 Pangkalan Susu.

Dari Hasil Uji determinasi menerapkan seberapa persen pengaruh. Rangkuman hasil tersebut disajikan dalam tabel berikut.

Tabel 5. Hasil Uji Koefisien Determinasi

\begin{tabular}{lcrrr}
\hline \multicolumn{4}{c}{ Model Summary $^{\mathbf{b}}$} \\
\hline Model & $\mathrm{R}$ & R Square & Adjusted R Square & Std. Error of the Estimate \\
\hline 1 & $.368^{\mathrm{a}}$ & .136 & .121 & 6.973 \\
\hline a. Predictors: (Constant), kelas PBM & & \\
\hline b. Dependent Variable: posttest & & \\
\hline
\end{tabular}

Dari tabel di atas dapat dilihat bahwa besarnya pengaruh pembelajaran berbasis masalah untuk meningkatkan kemampuan komunikasi matematis siswa yang terlihat pada tabel diatas adalah sebesar 13,6 \%. Sedangkan 86,4\% nya dipengaruh oleh faktor lain. Namun berdasarkan hasil penelitian pengaruh yang peneliti temukan tidak mencapai $50 \%$ dikarenakan pada saat penelitian terlihat bahwa siswa kurang bersungguh-sungguh dalam pengerjaan tes. Sehingga pengaruh yang didapatkan hanya $13,6 \%$ pada pengaruh pendekatan pembelajaran berbasis masalah untuk meningkatkan kemampuan komunikasi matematis matematika pada siswa. 


\section{KESIMPULAN}

Berdasarkan analisis data yang telah disajikan dan pembahasan hasil penelitian yang telah diuraikan, dapat diambil kesimpulan sebagai berikut:

Kemampuan komunikasi matematis siswa dengan menggunakan pembelajaran berbasis masalah pada siswa SMP Negeri 1 Pangkalan Susu dapat dilihat dengan membandingkan rata-rata dua kelas, pada kelas eksperimen rata-rata kemampuan komunikasi matematis siswa dari hasil posttest, setelah diberi perlakuan, kelas eksperimen diperoleh rata-rata 75,53 sedangkan pada kelas kontrol diperoleh rata-rata 66,57. Maka dari hasil tes akhir diperoleh kemampuan komunikasi matematis siswa dengan penggunaan pembelajaran berbasis masalah (kelas eksperimen) lebih besar dari pada kemampuan komunikasi matematis siswa yang menggunakan pembelajaran konvensional (kelas kontrol).

Terdapat pengaruh penggunaan pembelajaran berbasis masalah terhadap kemampuan komunikasi matematis siswa SMP Negeri 1 Pangkalan Susu hal ini dapat dilihat dari hasil pengujian hipotesis, hasil yang diperoleh Ho ditolak dan Ha diterima. Pengambilan keputusan dapat dilihat dari melihat $\mathrm{t}$ hitung $(3,018)>\mathrm{t}$ tabel $(1,671)$ maka dapat disimpulkan bahwa rata-rata kemampuan komunikasi matematis kelas eksperimen lebih besar dari rata-rata kelas kontrol. Hal ini berarti terdapat pengaruh penggunaan pembelajaran berbasis masalah terhadap kemampuan komunikasi matematis siswa SMP Negeri 1 Pangkalan Susu. Besarnya pengaruh pembelajaran berbasis masalah untuk meningkatkan kemampuan komunikasi matematis siswa adalah sebesar 13,6\% sedangkan $86,4 \%$ dipengaruh oleh faktor lain

\section{DAFTAR PUSTAKA}

Amir. M. (2013). Inovasi pendidikan melalui problem based learning bagaimana pendidik memberdayakan pemelajar di era pengetahuan. Jakarta: Kencana.

Ansari, B. I. (2012). Komunikasi matematik dan politik. suatu perbandingan: Konsep dan aplikasi. Banda Aceh: PeNa.

Arends, R. I. (2008). Learning to teach. Yogyakarta: Pustaka Pelajar.

Elfrida. (2013). Upaya meningkatkan kemampuan pemecahan masalah dan komunikasi matematik siswa sekolah menengah atas melalui pembelajaran berbasis masalah. Tesis tidak diterbitkan. Medan: Universitas Negeri Medan.

Handayani, A., Mukhni., \& Nilawasti, Z. A. (2014). Analisis kemampuan komunikasi matematis siswa melalui pendekatan pendidikan matematika realistik (PMR) bagi siswa kelas VII MTsN Lubuk Buaya Padang TP. 2013/2014. Jurnal Pendidikan Matematika, 3(2),1-6.

Saragih, S. \& Rahmiyana. (2013). Peningkatan kemampuan komunikasi matematis siswa SMA/MA di Kecamatan Simpang Ulim melalui model pembelajaran kooperatif tipe STAD. Jurnal Pendidikan dan Kebudayaan, 19(2), 188-174.

Saylan, A. (2013). Perbedaan kemampuan komunikasi dan kreativitas matematik antara siswa yang mendapatkan pembelajaran penemuan terbimbing berbasis masalab open ended dengan siswa yang mendapat pembelajaran ekspositori. Tesis tidak diterbitkan. Medan: Universitas Negeri Medan. 